Eva Blomdahl är doktorand vid Forskarskolan i naturvetenskapens och teknikens didaktik vid Linköpings universitet samt verksam som lärarutbildare i teknikämnets didaktik vid Lärarhögskolan i Stockholm. I det egna forskningsarbetet uppmärksammar författaren teknikämnet och teknikundervisningens praktik i grundskolans tidigare år. Avhandlingen syftar till att ta reda på hur skolämnet teknik formuleras till pedagogisk handling i två lärares praktiker.

\title{
Att undervisa i teknik - försök till en utbildningsfilosofi utifrån Heidegger och Dewey
}

\begin{abstract}
This paper presents an attempt to articulate a philosophy of education with respect to technology. The guiding idea is that the primary aim of technology education should be to help pupils to reflect on the nature of technology as a social and cultural phenomenon, as regards its effects on individuals, their society and the environment. Bearing in mind Heidegger's ideas on the essence of technology and Dewey's philosophy of education, a notion of technology education as "technology re-presentation" is introduced. This process centres on the visualisation or construction of technical systems and artefacts with a view to understanding them in the way indicated above. As far as the nature of this understanding is concerned, directives are given by Heidegger's idea of a reflection (Besinnung) on the impact of technology on our present world-view and by Dewey's concept of "reflective thinking", which refers to the insight into the relation between our actions and their consequences.
\end{abstract}

This article is a translated and reworked version of a previously published book chapter in English (Blomdahl, 2005).

\section{OM FILOSOFI SOM BAS FÖR TEKNIKUNDERVISNING}

Teknikämnet är det senast införda obligatoriska ämnet i svensk grundskola och har en kort historia jämfört med andra ämnen. Under de 30 år som jag har arbetat med undervisning i grundskolan har ämnet ändrat karaktär. I viss mån kan denna förändring betraktas som en återspegling av de tekniska framsteg som gjorts i vårt samhälle i stort: från att ha varit ett rent verkstadstekniskt tillvalsämne under 1960- och 1970-talen blev teknik under 1980-talet en form av tillämpad naturvetenskap, obligatorisk för alla. Ett nytt styrdokument utformades för grundskolan 1994, Lpo 94 (Skolverket, 1994a; b). För teknikämnets del betyder detta styrdokument att ämnet får egen kursplan. Ämnet får alltså egen ämnesstatus och är inte längre underordnat något annat kunskapsområde. Den nya kursplanen omfattar skolår 1 till och med skolår 9. Idag 10 år efter införandet av denna kursplan kvarstår dock svårigheter rörande ämnets identitet, innehåll och arbetssätt. Rapporter från fältet visar att teknikundervisning endast förekommer i liten utsträckning i skolorna idag (se Nationellt resurscentrum för teknikundervisning i förskola och skola (CETIS) genomförda enkätundersökning 1998/1999 i Skogh 2001; samt uppföljning CETIS enkätundersökning, 2003/2004 i Ginner (in press); Fabricius, Malm \& Pisilä, 2002). Det finns dessutom ännu så länge endast lite forskning rörande grundskolans teknikämne i Sverige, samtidigt som tecken visar på att forskningen idag är inne i en utvecklingsfas (Hagberg \& Hultén, 2005). Det saknas med andra ord en ordentlig diskussion om teknikämnet och min förhoppning är att denna artikel kan bidra till en offentlig debatt kring innehåll och arbetssätt i grundskolans teknikämne. 
En personlig övertygelse har efterhand växt fram om vikten av att utifrån de riktlinjer som ges i kursplanen förankra utformningen av teknikämnet i grundskolan i ett teoretiskt och filosofiskt resonemang. När ett nytt ämne introduceras initieras en process, vars riktning måste utstakas för att därigenom förse lärare med de redskap de behöver för att kunna utveckla sitt ämne. Det räcker inte med en kursplanetext och undervisningsexempel, utan till detta måste läggas en systematisk reflektion över teknikämnet, till vilken lärare kan vända sig för att få stöd i sin egen pedagogiska praktik.

Det finns med andra ord ett uttalat behov av en utbildningsfilosofi som kan formulera ett teoretiskt ramverk för utbildningen i teknik, annars riskerar denna att förbli rent empirisk och praktisk, utan någon egentlig grund vad dess innehåll, metod och övergripande syfte beträffar. Denna artikel är tänkt som ett bidrag till en sådan utbildningsfilosofi. Förutom att diskutera de nyss nämnda frågorna om teknikämnets natur, är avsikten att formulera vissa grundläggande begrepp som skulle kunna fungera som hörnstenar i teknikundervisningen, och på så sätt ge lärare en fingervisning om vad som är centralt i deras verksamhet.

Ett grundläggande antagande i detta sammanhang är således att filosofi bör utgöra basen för teknikundervisning, där filosofin rör både teknikens och undervisningens natur (för denna idé, se även Williams, 1996). Av den anledningen har jag i föreliggande artikel valt att vända mig till de två filosoferna Martin Heidegger och John Dewey, för att med deras hjälp utveckla vissa idéer relaterade till teknikundervisning. Medan Heidegger främst bidrar med en filosofi om teknik, erbjuder Dewey en filosofi om undervisning och lärande. Dessa filosofer behandlas i syftet att utarbeta ett begrepp om teknikundervisning som jag har valt att kalla "teknikre-presentation". Teknikre-presentation är ett uttryck som är tänkt att föra tankarna till det att presentera eller att visa något. I teknikundervisningen re-presenterar eller återger vi något faktiskt existerande. Prefixet "re-" ska således fånga detta att vi på nytt lär oss betrakta världen, den dagliga värld vi lever i, med fräscha ögon; vi "uppdagar" den, som Heidegger (1974/2004) skriver. Re-presentation anknyter också till begreppet "representationsformer" för att fästa uppmärksamheten på att det finns andra språk än de verbala och aritmetiska (se Bruner, 1970; 1990; Säljö, 2000; Kress, 2003).

Den övergripande målsättningen med teknikre-presentation är att hjälpa elever till ett slags visualisering av artefakter och system av artefakter i syftet att förstå dem i enlighet med vissa bestämda perspektiv och utgångspunkter. Teknikre-presentation är en kunskapsgenererande process i vilken teori och praktik är sammanvävda. I undervisningen kommer denna process att anta en form som påminner om ingenjörens, industridesignerns och framförallt arkitektens gestaltande arbetssätt. Men till skillnad från dem kommer inte eleverna i skolan att uppfinna eller utveckla tekniska produkter, utan arbeta med att förstå teknikens uppkomst och funktion, såväl som dess effekter på människa, natur och samhälle. Som vi ska se innebär detta att teknikre-presentation omfattar två olika förklaringsnivåer eller perspektiv: ett inom- och ett utomtekniskt. För även om undervisningen förvisso utgår från den gängse, i grund och botten antika synen på teknik som skapande och produktion, så övergår den så småningom till att analysera denna uppfattning utifrån ett vidare, samhälleligt perspektiv. I slutändan handlar alltså teknikre-presentation helt enkelt om att med tekniken som ledtråd försöka nå insikt i människans grundläggande livsvillkor, så som detta har beskrivits hos Heidegger och Dewey.

I det följande kommer jag att försöka förklara de olika aspekterna av teknikre-presentation samt de faser som omfattas av denna process. Inledningsvis kommer syftet med utbildning i teknik att behandlas och några filosofiska utgångspunkter för teknikundervisning att presenteras innan försöket med att förklara teknikre-presentation samt de faser som omfattas av processen tar vid. 


\section{Syftet med utbildningen I teknik I luUSet AV Heidegger och DeWeys ARbeten}

Inledningsvis kan det vara värt att se hur teknikämnets övergripande målsättning presenteras i kursplanen för teknik:

Utbildningen i ämnet teknik utvecklar en förtrogenhet med teknikens väsen. Syftet är att öka förståelsen av hur produktionsförhållanden, samhället, den fysiska miljön och därmed våra livsvillkor förändras.

(Kursplanen i teknik, Skolverket, 1994b, s. 1)

Ett annat syfte är att "så långt som möjligt göra vardagstekniken begriplig och synlig" (ibid.), vilket tillsammans med ovanstående citat låter oss urskilja två centrala målsättningar: att göra eleverna förtrogna med hur tekniken själv fungerar, dvs. dess apparater, system, processer, etc., samt att ge eleverna tillfälle att reflektera över tekniken utifrån ett vidare, utomtekniskt perspektiv, där tekniken ses som en samhällelig företeelse, som har betydelse för människans livsvillkor i dess helhet. I denna artikel skulle jag vilja föreslå att det förra utbildningsmålet bör underordnas det senare, vilket kortfattat innebär att utbildningen i teknik i första hand syftar till att hjälpa eleverna att bli kompetenta, reflekterande medborgare, snarare än att bara göra dem tekniskt kunniga i snäv mening.

Flera moderna tänkare som Heidegger, Ortega y Gasset, Spengler m.fl. har vittnat om att det finns anledning att betrakta tekniken inte bara som en företeelse bland andra i vårt samhälle utan som ett absolut grundläggande fenomen, som kan säga oss något viktigt om den moderna människans sätt att se på sig själv och sin omvärld (Heidegger, 1974/2004; Ortega y Gasset, 1957; Mitcham, 1994). Om detta är riktigt, så är teknikämnet faktiskt särskilt lämpat att ge eleverna en fördjupad förståelse av sig själva som medborgare i dagens samhälle. Detta är med andra ord anledningen till ovannämnda rangordning av utbildningsmålen för teknikämnets del. Men i så fall kan uppenbarligen inte den i kursplanen omnämnda förtrogenheten med teknikens väsen tolkas i termer av rent tekniska, "inomdisciplinära" kunskaper, utan måste utvidgas till att inbegripa en reflektion över människan belägenhet i vår tekniska tidsålder. Liknande tankegångar återfinns hos Heidegger, som förmodligen har diskuterat frågan om teknikens väsen mer djupgående än någon annan. Med sina rötter i fenomenologi och transcendentalfilosofi, som ytterst går tillbaka till Kant, såg Heidegger det som sin huvudsakliga uppgift att frilägga och begreppsliggöra vår erfarenhet med avseende på dess grundläggande betingelser, och det är mot denna bakgrund som hans intresse för tekniken måste ses. I kraft av sitt vidare, mer kunskapsteoretiskt orienterade perspektiv, skiljer sig Heidegger, såvitt jag kan se, från i stort sett alla andra som har befattat sig med tekniken. Dessa har mer intresserat sig för tekniken "i sig", som ett samhälleligt fenomen rätt och slätt. Men tack vare sitt speciella perspektiv är Heideggers tänkande inte bara till hjälp i den inte helt lätta frågan om vad teknik egentligen är, utan rymmer också idéer som är värda att ta fasta på i samband med försöket att avgöra vad för slags kunskap som teknikundervisningen bör syfta till. Heidegger har nämligen försökt visa varför det är nödvändigt att se bortom det ensidigt tekniska synsätt som han ansåg utmärka sin samtid till förmån för en kritisk reflektion över teknikens förutsättningar och roll i samhället (Heidegger, 1974/2004).

Även Dewey kan sägas omfatta detta perspektiv i sin utbildningsfilosofi, i och med att han tänker sig att skolan vid sidan av sina uppenbara, så att säga rent utbildningsmässiga mål även har som uppgift att behandla sina elever som medborgare att utbildas för demokratiska och medborgerliga syften (Dewey, 1959b/1997). Mer precist utgör det senare faktiskt skolans viktigaste uppgift, enligt Dewey. Han är en av den så kallade pragmatismens främsta företrädare, med en stor produktion av filosofisk litteratur rörande frågor som berör skolan, och den nu gällande läroplanen för grundskolan i Sverige (Skolverket, 1994a) genomsyras av hans syn på utbildning. I Demokrati och utbildning (Dewey, 1959b/1997) argumenterar han för att undervisning och lärande bör ses som samhällets främsta socialiseringsinstrument, eftersom de utgör de processer 
genom vilka vår kultur återskapas från en generation till en annan. I linje med detta perspektiv betraktas utbildning huvudsakligen som ett socialt fenomen, som en integrerad del av samhället. Enligt Dewey kännetecknas det sociala livet av en överföring av grundläggande idéer och åsikter mellan samhällets medlemmar. När även skolan betraktas utifrån ett samhälleligt perspektiv blir denna överföringsprocess en viktig utgångspunkt för utbildningen. Livet självt blir med andra ord kunskapens främsta föremål.

Utifrån Dewey och Heidegger skulle jag alltså vilja föreslå att det som varit den traditionella teknikundervisningens primära syfte, att förse eleverna med specifikt teknisk kunskap, borde underordnas den övergripande målsättningen att göra eleverna i stånd att reflektera över tekniken som ett socialt och kulturellt fenomen. Innan jag går in närmare på frågorna rörande innehållet $\mathrm{i}$ teknikundervisningen samt hur denna bör struktureras ger jag i följande avsnitt en presentation av Heideggers förståelse av den moderna tekniken, då denna i hög grad ligger till grund för det förslag till utformning av teknikundervisningen som sedan kommer att utarbetas.

\section{HEIDEGGERS IDÉ OM TEKNIKENS VÄSEN}

Som sades tidigare är Heideggers främsta filosofiska intresse egentligen det att förstå erfarenhetens grundläggande betingelser överhuvudtaget, och det är av den anledningen som han så småningom i sitt författarskap kom att vända sig till tekniken, vilken blir till ett slags symbol för den moderna tidsåldern som sådan. En av Heideggers mest grundläggande idéer i detta avseende är att teknikens väsen inte självt är något tekniskt, och därför inte kan förklaras med hänvisning till det tekniska hantverket eller de apparater och verktyg som tekniken gör bruk av. Detta innebär att det specifikt tekniska vetandet inte medger någon egentlig förståelse av teknikens sanna natur; den är förbehållen den filosofiska reflektionen. En ytterligare konsekvens är att Heidegger ställer sig kritisk mot den instrumentella synen på tekniken, enligt vilken tekniken väsentligen är ett mänskligt redskap, till för mänskliga behov. (Heidegger, 1974/2004). Han menar i stället att en förståelse av teknikens väsen kan uppnås först när vi inser vad för slags verklighetsuppfattning som den moderna tekniken inte bara ger uttryck för utan även grundar sig på. Frågan om teknikens väsen blir på så sätt en fråga om vår förståelses natur och förutsättningar. För Heidegger blir därför "teknik" i slutändan helt enkelt namnet på den moderna människans världsbild. Med denna betydelseförskjutning introducerar han inte bara ett nytt perspektiv på tekniken, utan argumenterar också varför detta är absolut nödvändigt. Häri ligger också hans betydelse för frågor knutna till undervisning i teknik: enligt hans synsätt är teknikundervisning inget annat än en introduktion i människans livsvillkor - vare sig vi vet om det eller ej.

För att kunna anlägga detta vidare perspektiv på den moderna tekniken måste vi, tänker sig Heidegger, gå tillbaka till det antika teknikbegreppet, techne, i syftet att se vad för slags verklighetsuppfattning det implicerar. Aristoteles, som är den förste att noggrant utreda detta begrepp, tänker sig att det betecknar en form av kunskap eller färdighet som styr poiesis, framställning eller produktion. Techne utmärks av sin insikt i hur ett givet ändamål kan uppnås. Ändamålet är något som ska framställas, t.ex. ett hus, och den tekniska kunskapen består följaktligen i ett fattande av de medel med vilka ändamålet i fråga låter sig realiseras (Aristoteles, 1988). Att på detta sätt beskriva den tekniska färdigheten i termer av mål och medel är emellertid utmärkande just för den instrumentella synen på tekniken. När Heidegger (1974/2004) i uppsatsen "Teknikens väsen" tar sig an uppgiften att analysera det antika teknikbegreppet koncentrerar han sig därför inte på det tekniska hanterandet som sådant. I centrum för hans diskussion står istället det elementet av förståelse som ligger i techne, och särskilt dess föregripande av framställningens mål. Det mål som den tekniskt kunnige måste gripa i förväg utgörs inte av en produkt rätt och slätt, utan mer precist är det produktens form som måste vara given på förhand för att framställningen ska kunna komma igång. Denna form, som i grekernas ögon är evig och oföränderlig, och som därför ligger bortom det som människan kan påverka, är med andra ord en princip för eller orsak till det framställda föremålets karaktär och särart. 
Denna beskrivning visar att det väsentliga hos techne och poiesis faktiskt inte är produktionen som sådan utan dess moment av förståelse av det färdiga föremålets utseende (Heidegger, 1974/2004). Man skulle kunna säga att det tekniska framställandet inte längre direkt ses som ett skapande utan som ett sätt att göra något närvarande. I den tekniska processen görs ett föremål närvarande genom att det framställs, eftersom detta innebär att föremålet går från att vara blott tänkt till att få konkret fysisk form, med utgångspunkt i något som på sätt och vis redan var närvarande eller existerade, nämligen föremålets oföränderliga och oskapade utseende. Heidegger drar så den preliminära slutsatsen att teknikens väsen utgörs av ett slags "sanningsskeende", från grekiska aletheuein, i vilket något uppdagas eller görs tillgängligt för människan.

Techne är en form av aletheuein. Den uppdagar sådant som inte frambringar sig självt och som ännu inte föreligger, och som därför kan se ut och utfalla än på det ena, än på det andra sättet. ... Det avgörande $i$ techne ligger sålunda inte $i$ bearbetningen och hanteringen, inte $i$ användningen av medel, utan i det nämnda uppdagandet. Som sådant, och inte som förfärdigande, är techne ett frambringande.

(Heidegger, 1974, s. 23)

På så sätt leder alltså synen på teknik som produktion över till en idé om teknik som ett sätt att uppfatta verkligheten som sådan. Teknik i traditionell mening kan inte förstås om vi inte tar steget mot en analys av människans belägenhet i stort.

Men, påpekar Heidegger, när det gäller att fatta den moderna tekniken är inte det grekiska begreppet om techne tillräckligt, om än en nödvändig utgångspunkt. Anledningen är att den grekiska verklighetsuppfattningen skiljer sig från vår på ett avgörande sätt. Utmärkande för den moderna tekniken är nämligen att den är grundad i en erfarenhet av världen som bestånd eller resurs, som är till för människan att exploatera. Detta är något annat än att som i antiken erfara världen med avseende på dess utseende, för detta implicerar ett visst avstånd mellan människan och naturen, vilket kommer sig av att tingens former ses som eviga och därmed inte skapade av människan. Detta avstånd går emellertid förlorat när naturen ses som bestånd, för i och med detta förstås den inte längre som en i grunden självständig storhet som människan kan undersöka på olika sätt, utan som en resurs som inte har någon självständig existens bortom människans behov. I stället för att som techne betrakta en av mänskligt hanterande oberoende natur, utmanar (herausfordern) den moderna tekniken naturen, dvs. tvingar den att underkasta sig det tekniska hanterandets krav, utan att "se efter" hur naturen i själva verket är beskaffad (Heidegger, 1974/2004).

Med denna diagnos av teknikens väsen har Heidegger som synes även försökt visa på nödvändigheten av en kritisk reflektion över tekniken. På så sätt leder han oss mot frågan om vad det rätta förhållningssättet till tekniken kan tänkas vara. I Heideggers ögon är det lika meningslöst att naivt bejaka den moderna teknikens utveckling som att fördöma den som fasansfull, för båda dessa förhållningssätt vilar på den instrumentella synen på tekniken. Men tekniken står inte i människans tjänst som ett medel, fritt för henne att förfoga över eller att avstå från. Snarare är det vi som är ett medel för tekniken: den rådande tekniska verklighetsuppfattningen gör bruk av eller utmanar oss, för tekniken fungerar bara under förutsättning att vi förstår oss själva och vår omvärld på ett visst sätt, nämligen som resurser som kan utnyttjas för bestämda syften (Heidegger, 1974/2004).

Vi måste alltså acceptera att vi lever och verkar inom ett tekniskt förhållningssätt till vår omvärld, i enlighet med vilket vi erfar allt som medel för mänskliga mål. Vad vi kan och måste göra är att betänka just detta. Faran med den moderna tekniken är först och främst att den hotar att reducera vårt perspektiv på världen, så att den rikedom av betraktelsesätt som faktiskt finns går förlorade. Som redan antytts medför tekniken dessutom en felaktig självbild för 
människans del: den förleder oss att tro att vi är herrar över världen och oss själva, när vi i själva verket är slavar under tekniken. Men i denna till synes dystra belägenhet ligger en sanning värd att beakta: att tekniken så att säga använder oss för att härska antyder att vårt väsen ligger i att utgöra den "plats" där verkligheten mottas och ges mening. Även om vi inte kan styra över den rådande verklighetsuppfattningen, så skulle en sådan inte finnas utan vår medverkan, eftersom verkligheten, och därmed tekniken, måste tolkas och gestaltas för att få mening och påverka oss (ibid.).

Det gäller därför att försöka förstå denna relation mellan människa och teknik, och för detta syfte behövs ett nytt slags tänkande, som inte bara naivt håller sig inom den tekniska världsåskådningens ramar, utan förmår reflektera över teknikens väsen. I uppsatsen "Vetenskap och besinning" karaktäriserar Heidegger (1974/2004) det tekniska och överhuvudtaget det vetenskapliga tänkandet i termer av "bildning", en term som har sina rötter i romantiken, vars bildningsideal Heidegger alltså önskar ifrågasätta genom att visa hur det fortfarande gör sig gällande i teknikens epok. Han vill komma åt teknikens produktiva eller "bildande" karaktär, vilket består i att den utgår från en "före-bild", dvs. ett givet mål som ska realiseras. Förebilden är i sista hand det tekniska paradigm som det vetenskapliga tänkandet inte ifrågasätter, eftersom detta tvärtom utgör en förutsättning för att vetenskapen ska kunna gå framåt och producera resultat och nya rön. Ett sådant tänkande utesluter alltså ett kritiskt frågande, just genom att det på förhand har bestämt vad det ska komma fram till.

Detta synsätt äger naturligtvis sitt berättigande men måste kompletteras med ett eftertänksamt, kritiskt tänkande, som förmår reflektera över människans plats i världen i teknikens tidsålder och kan se att människan nu erfar naturen som bestånd, etc. Heidegger kallar detta tänkande "besinning”. Besinningen är inte produktiv, utan tar så att säga ett steg tillbaka i och med att den riktar sig mot något som är givet på förhand. Eftersom Heidegger tänker sig att vi inte helt och hållet råder över teknikens väsen beskriver han ofta försöket att förstå det som ett slags förberedelse eller väntan. Vad det innebär att vara människa i teknikens tidsålder har inte ett enda, definitivt svar, utan är historiskt föränderligt (vilket ju jämförelsen mellan den antika och den moderna verklighetsuppfattningen har antytt). Besinningen får därför dras med osäkerhet: den riktar sig mot en osäker framtid.

Genom den så förstådda besinningen når vi just fram dit där vi, utan att ännu erfara och genomskåda det, redan sedan länge uppehåller oss. I besinningen rör vi oss $i$ riktning mot en ort utifrån vilken för första gången det rum öppnar sig som vårt nuvarande görande och låtande genomkorsar.

(Heidegger, 1974, s. 83)

Heidegger kan alltså vara till hjälp i försöket att förstå vad teknik är och vad det skulle kunna innebära att reflektera över den som ett för vår kultur karaktäristiskt fenomen. I kraft av sin diskussion av förhållandet mellan de två grundläggande perspektiven på teknik ger han oss ett förslag på vad som skulle kunna ingå i teknik som skolämne. Även om Heidegger inte hänvisar till utbildning i sin diskussion, så finns det något fruktbart i hans tänkande utifrån ett skolperspektiv, eftersom en central målsättning där är att eleverna just ska utveckla sin förmåga till att kritiskt granska fakta och relationer och inse konsekvenserna av olika alternativ. Genom att hjälpa eleverna till översikt och analys på detta sätt kan skolan göra dem kapabla till att orientera sig i dagens komplexa verklighet.

Med denna analys av tekniken i bakhuvudet vänder vi oss nu lämpligen till de mer renodlat didaktiska frågeställningar som nämnts tidigare. Diskussionen av dessa lutar sig i hög grad mot Deweys arbeten, även om Heideggers idéer även fortsättningsvis utgör en bakgrund. Men innan jag tar upp frågan om teknikundervisningens innehåll skulle jag vilja diskutera frågan om dess metod, så som den har behandlats av Dewey. Denna ordning kan kanske tyckas en smula märklig, men den motiveras av det faktum att frågan om metod för Dewey i hög grad är en fråga om den rätta början eller utgångspunkten inom undervisning. 


\section{FRÅGAN OM UNDERVISNINGSMETOD}

\section{Vikten av att ge gynnsamma förutsättningar och en fruktbar miljö}

När utbildningens mål inte koncentreras till inlärning av tekniska baskunskaper utan förstås i termer av en ökad förmåga till analys och reflektion, blir frågan om undervisningens metod av särskild vikt. Men det blir också svårare att besvara denna fråga på ett generellt och definitivt sätt, eftersom det är en betydligt vanskligare uppgift att lära ut tänkandet som sådant jämfört med att bara förmedla fakta. Detta synsätt är också centralt för Dewey (1959b/1997), som i sin diskussion av undervisningsmetoder följaktligen avstår från att ge någon exakt modell att följa steg för steg. I hans ögon vore detta tvärtom förödande för undervisningsprocessen, då det leder till stereotypa rutiner som inte ger något utrymme åt det kreativa element som utgör en nödvändig förutsättning för allt sant lärande. I stället betonar Dewey vikten av att som lärare frambringa goda tankevanor, och skriver att tänkande är "den bildande erfarenhetens metod" (Dewey, 1997, s. 208). För att förbättra metoderna för undervisning måste vi uppmärksamma vad som gynnar och utmanar tänkandet, som kan sätta det i rörelse genom att uppmuntra det. Denna syn på metod hänger samman med Deweys övertygelse att skolan måste låta sina elever ta aktiv del i formulerandet och lösandet av problem, i stället för att behandla dem som passiva mottagare av ett redan fastlagt kunskapsstoff. Ur det perspektivet blir lärandets själva process, dess "hur", lika viktigt som dess innehåll. Syftet med metoden är därmed att frambringa en så produktiv eller insiktsfull erfarenhet som möjligt genom att möjliggöra det som Dewey kallar "reflekterande tänkande", vilket kommer att behandlas nedan.

Hur kan då lärare med sina metoder lyckas frambringa den produktiva insikt som nyss nämndes, och på så sätt hjälpa sina elever att bli ansvarsfulla och reflekterande subjekt? En tanke som Dewey förde fram i början av förra seklet är att den värld barn och ungdomar lever i blir alltmer osynlig och att skolans uppgift är att göra den synlig igen. Denna tankegång är än mer aktuell nu, med tanke på den smått otroliga tekniska utveckling som har ägt rum under det senaste århundradet, vilket har gett oss enorma mängder av kunskapsstoff. Denna kunskapsexplosion gör att idag är mängden av information så stor att det är omöjligt för den enskilde individen att greppa allt. Dewey, som var verksam under den första delen av förra århundradet, kunde redan då se hur eleverna i skolan överhopades av en kunskapsmängd som inte var kopplad till deras egna erfarenheter eller förmågor. Resultatet blir att eleverna i skolan konfronteras med en främmande värld, som är frikopplad från deras egen. Uppgiften blir då att lära för skolans skull, för prov, förhör och betyg, vilka Dewey kallar för denna skolvärlds hörnstenar. För att kunna omorganisera lärandet så att det blir meningsfullt, föreslår Dewey därför att undervisningen måste vara erfarenhetsbaserad och erfarenhetsskapande (Dewey, 1959b/1997).

I Demokrati och utbildning försöker Dewey (1959b/1997) visa att lärandets mål måste vara att lära om vår värld som vi erfar den. Både teori och praktik är komponenter i den processen. Lärandets mål är i första hand att ge eleverna möjligheten att förstå och använda sig av sina erfarenheter. Detta blir möjligt när eleverna får utveckla de reflektiva tankeprocesser med vilka de kan granska sina upplevelser. Genom reflektion kan erfarenheterna generaliseras och användas i nya situationer.

I varje erfarenhet är intresset drivkraften; det undervisningen handlar om måste väcka nyfikenhet och engagemang (Dewey, 1959a). Eleverna måste uppleva att aktiviteterna och konsekvenserna av dessa har relevans för deras verklighet och liv. Därför tänker sig Dewey att intresse kan väckas endast om lärostoffets problem och frågor knyts till elevernas faktiska förmågor och deras konkreta situation. Olika miljöer ger olika erfarenheter, och det är lärarens ansvar att inte bara vara uppmärksam på att omgivningen rent generellt är av betydelse, utan också att konkret känna igen vilka omgivningar som gynnar elevernas utveckling. Detta har att göra med Deweys idé att kunskap endast kan förmedlas indirekt, via en påverkan av miljön. Lärarens uppgift är därför att ge 
förutsättningar för lärande just genom att förmedla en gynnsam miljö, men kunskapen som sådan måste eleven själv åstadkomma genom aktivt deltagande (Dewey, 1959b/1997).

En uppenbar aspekt av miljön eller omgivningen är interaktionen med andra människor. Kraften ligger i ömsesidigheten mellan det sociala och det individuella, där samspelet mellan dessa påverkar elevens tänkande, samtidigt som eleven i sin tur påverkar den miljö han eller hon befinner sig i. På så sätt är själva processen att leva tillsammans bildande. Eller som Dewey också uttrycker det "... all kommunikation (och därmed allt verkligt och socialt liv) är bildande. Att kommunicera med sin omgivning innebär att man får en förändrad och utvidgad erfarenhet” (Dewey, 1997, s. 39).

\section{Platsen som centralt begrepp inom teknikundervisningen}

Idén att man i undervisningsprocessen måste ta hänsyn till elevernas situation och bakgrund kan också motiveras med hänvisning till Heidegger och hans idé om förståelse som en av situationen väsentligen bestämd process; om man ignorerar den lärandes situation går man följaktligen miste om ingenting mindre än själva basen för lärande och förståelse. I uppsatsen "Bygga bo tänka" utvecklar Heidegger (1974/2004) en idé om det mänskliga tänkandets och handlandets bundenhet till en "ort", enligt vilken människan alltid befinner sig i en bestämd situation, där vissa omständigheter är givna, vilka bestämmer hennes förståelse och hennes sätt att förhålla sig till sin omvärld. Det är just genom vårt hanterande av de ting som omger oss som denna situation upprättas eller aktualiseras; ett skeende som utmärks av att det begränsar våra möjligheter till förståelse och handling, eftersom vad som låter sig göras med vissa saker och i vissa situationer är omöjligt under andra omständigheter. Detta innebär dock inte att begränsningen ska ses som något negativt, något som hindrar oss i vårt handlande och tänkande. Tvärtom möjliggör den förståelse och handling, för utan begränsning skulle dessa aktiviteter sakna riktning.

Men den situation som man alltså bör ta hänsyn till i undervisningen rör inte bara elevernas förståelse och dess förutsättningar. Som Heidegger (1974/2004) har visat hör den så att säga även till tingen själva, dvs. de tekniska apparater och verktyg eleverna träffar på i samband med teknikundervisningen. Detta innebär att vi inte kan förstå de tekniska apparaternas och verktygens väsen om vi bara betraktar dem som isolerade föremål. För tingen bär i själva verket upp en hel värld genom att peka utöver sig själva, mot ett sammanhang eller en livsvärld där de har sin plats och funktion. I de olika formerna av teknisk bearbetning deltar sålunda eleven i inrättandet av sin situation och därmed också i skapandet av den värld eller det samhälle vi alla lever i. Här kan vi se hur det inom- och utomtekniska perspektivet knyts ihop: den specifikt tekniska kunskapen om tekniska apparater och system visar hän mot det vidare sammanhang, dvs. i sista hand vår värld, $\mathrm{i}$ vilken den ingår, vilket innebär att det förra förutsätter en förståelse av det senare.

Som ovanstående resonemang förhoppningsvis gjort klart utgör tekniken ett rikt och mångfacetterat landskap för lärande. Det är mot bakgrund av detta omfattande landskap som eleverna sätter sig in i tekniska, ekonomiska och samhälleliga frågor. Utifrån Heidegger och Dewey kan man hävda att teknikundervisningen bör äga rum i interaktion med verkligheten både i och utanför skolan. För att tydliggöra förskjutningen från klassrummet till samhället införs därför begreppet "plats" som arena för lärande. "Plats" är en konkret term för omgivning. Ett vanligt språkbruk är att handlingar och skeenden "äger rum". Det är meningslöst att tänka sig ett skeende utan referens till en lokalitet. Att höra till en plats innebär att ha ett existentiellt fotfäste i en konkret och vardaglig bemärkelse. På så sätt anknyter platsbegreppet, så som det kommer att användas i samband med begreppet om teknikre-presentation, till Heideggers idé om den mänskliga förståelsens "ort”. Men platsbegreppet tar även fasta på Deweys övertygelse att lärandet måste utgå från elevens konkreta erfarenhet och situation. Platsen är elevens närmiljö, hem, skola, ort. Platsen med sin tekniska miljö bestående av system och artefakter är elevens existentiella fotfäste - hans eller hennes navigationsinstrument i verkligheten. Platsen blir teknikämnets egentliga innehåll. För att eleverna ska 
förstå de processer som formar teknikens framväxt, utveckling och användning i samhället, måste de kunna relatera till denna plats, bl.a. genom att få upp ögonen för att teknik inte kan identifieras med enskilda artefakter utan måste ses som delar av ett helt system (se även Summerton, 1998). Olika typer av kunskap och artefakter måste därför kombineras i undervisningen utan hänsyn till strikta ämnesindelningar.

\section{Teknikre-presentationens första steg: uppdraget}

Teknikre-presentation börjar med att ett problem utvecklas som stimulerar tänkandet - ett uppdrag. Det kan handla om förbättringar av existerande system eller produkter, uppfinningar, skapandet av nya idéer, eller bara utvecklandet av en eller annan teknik. I samband med undervisning är det vanligt att använda ordet "problem". Jag föredrar "uppdrag" i stället, eftersom problem är förknippade med svårigheter och bekymmer. Uttrycket "problemlösning" kan också ge intryck av att det bara finns endast en lösning. Ett uppdrag däremot utgör en formulering som antyder en riktning, vilket öppnar för flera typer av lösningar.

Detta synsätt är i linje med Deweys ide att den första fasen av undervisningen inleds när eleven försätts i en "sann erfarenhetssituation" (Dewey, 1997, s. 208). Det ska vara en situation som eleven är intresserad av för dess egen skull, ur vilken ett uppdrag utvecklas som stimulerar elevens tänkande. Konsten som lärare ligger i att ge uppdrag som är svåra nog att utmana tänkandet utan att eleven förlorar sin egen utgångspunkt:

I believe that we violate the child's nature and render difficult the best ethical results, by introducing the child too abruptly to a number of special studies, of reading, writing, geography, etc., out of relation to this social life. I believe, therefore, that the true center of correlation on the school subjects is not science, nor literature, nor history, nor geography, but the child's own social activities.

(Dewey 1959a, s. 25)

Teknikre-presentationsprocessen tar följaktligen sin utgångspunkt i elevernas värld, deras omgivning och bakgrund. Och som redan har sagts är detta också anledningen till att begreppet om plats bör ges en central roll i undervisningen, både i bemärkelsen av elevens konkreta situation, så som detta förklarades ovan, och i den mer begränsade meningen av tekniska system och artefakter som föremål för studier.

\section{UNDERVISNINGENS INNEHÅLL}

\section{Analys och konstruktion/visualisering - teknikre-representationens steg två och tre}

Om teknikre-presentationens första steg, formulerandet av ett uppdrag, var intimt förknippat med frågan om metoder i undervisningen, så leder oss nästa steg, analysen, till frågan om innehåll. När ett uppdrag har valts är det elevernas uppgift att analysera existerande tekniska system för att på så sätt klargöra förutsättningarna för genomförandet av det aktuella uppdraget. I detta sammanhang bör vi på nytt påminna oss om Heideggers analys av tekniken, i synnerhet hans försök att kontrastera det antika synsättet på teknik gentemot sitt eget. På grund av dess betoning på relationen mellan mål och medel tänker ju sig Heidegger att det antika synsättet ligger till grund för det instrumentella, inomtekniska perspektivet på tekniken. Ett sådant perspektiv ger oss en inblick i den tekniska processens grundläggande struktur och väsentliga komponenter, vilket onekligen är av vikt för att förstå hur tekniken fungerar. Däremot säger det oss knappast något om teknikens samhälleliga betydelse eller dess påverkan på människa och natur, utan för detta krävs den vidare reflektion som av Heidegger benämns "besinning". Dewey har en liknande idé om vad äkta förståelse innebär, vad han kallar för "reflektivt tänkande". Med detta begrepp vill han fånga en typ av kunskap som enligt Dewey borde prägla elevernas lärande. 
Som redan visats ser Dewey elevernas erfarenhet som det centrala elementet i undervisningsprocessen. Erfarenheten kan uppdelas i primära och sekundära erfarenheter, där de förra utgörs av vår relativt omedelbara sinnliga erfarenhet av verkligheten. Dessa upplevelser inbegriper inte i sig någon egentlig kunskap, däremot utgör de utgångspunkten för de sekundära upplevelserna genom att förse dem med stoff eller föremål. För medan de förra inskränker sig till att omfatta en förståelse av att saker förhåller sig på ett visst sätt, t.ex. att ett hus används för att bo i, inbegriper de senare en insikt i hur eller varför förhållandet ser ut som det gör, t.ex. hur ett hus måste vara konstruerat för att fungera. (Dewey, 1959b/1997). De sekundära upplevelserna utmärks följaktligen av sin reflekterande karaktär, vars syfte är att ordna och förklara de primära erfarenheterna.

Erfarenheten inbegriper både ett passivt och ett aktivt element som kombineras. Den aktiva delen består i att man gör något, försöker och prövar, medan den passiva delen handlar om att utstå följderna av den aktiva fasen. Hur värdefull erfarenheten är beror av sambandet mellan dessa två faser: "När vi genomför en aktivitet och utstår följderna och när den förändring handlingen orsakar reflekteras i en förändring inom oss blir själva omvandlingen laddad med betydelse. Vi lär oss något” (Dewey, 1997, s. 183). Lärande kan alltså inte förstås endast i termer av experiment, utan det är först när den passiva fasen läggs till och vi utsätts för konsekvenserna av experimentet, som en verklig erfarenhet kommer till stånd. Dess värde ligger i den kunskap om sammanhang och relationer som den leder till, dvs. när den låter oss se inte bara att något sker till följd av något annat, utan varför det sker. Att på detta sätt medvetet försöka förstå sambandet mellan handlingar och deras resultat kallar Dewey "reflektion" eller "reflekterande tänkande" (Dewey, 1997, s.189). Detta är en av de mest centrala idéerna i Deweys utbildningsfilosofi.

Som nämndes ovan kan denna fas av undervisningen eller teknikre-presentationen kallas för "analys", vilken syftar till en förståelse av existerande tekniska system och artefakter som ska göra det möjligt att ta sig an det uppdrag från vilket man en gång tog avstamp. Detta blir möjligt när eleverna förmår förstå varför olika system och artefakter fungerar som de gör, varför de har vissa effekter på omgivningen, men inte andra, etc. Och som redan har antytts handlar detta i grund och botten om en förståelse av förhållandet våra handlingar och deras resultat, applicerat på det tekniska system eller artefakt som eleven analyserar för tillfället. Läraren har här uppenbarligen en viktig roll i sökandet och bearbetningen av information från olika källor och med olika typer av hjälpmedel.

Men lärande består inte endast i analyser av redan existerande material, utan inbegriper även en kreativ fas. Denna övertygelse drev Dewey att definiera lärandet som "konstant omorganisation eller rekonstruktion av erfarenheten" (Dewey, 1997, s. 116). Denna process är i princip utan slut, eftersom den inte endast utmärker utbildning i snäv bemärkelse, utan utgör en väsentlig del av livet själv. Detta har ju också redan antytts, när Deweys sociala perspektiv på utbildning introducerades. Lite förenklat kan man säga att han vill att skolans pedagogik ska följa livets eget lärande och typ av erfarenhetssituation, i stället för att tvinga på eleverna ett konstlat sätt att lära. Av den anledningen bör lärandet inte heller endast ses som ett medel för ett yttre, senare mål; det utgör ett mål i sig. Eller som Dewey själv formulerar det: "lärandets mål och belöning är fortsatt förmåga att växa" (Dewey, 1997, s.141). Allt tänkande i denna bemärkelse tar sin utgångspunkt i något oavslutat. Det innebär att tänkandet alltid rör något ovisst eller problematiskt. Målet med tänkandet blir då att nå fram till en - hypotetisk - slutsats genom att ta avstamp i något som redan är känt. Dewey skriver:

... tankar är ofullständiga så länge de bara är tankar. I bästa fall är de hypotetiska uppslag och indikationer. De är utgångspunkter och metoder för att hantera erfarenhetssituationer. Tills de tillämpas $i$ dessa situationer saknar de skärpa och verklighetsprägel. Det är i tillämpningen de prövas och bara genom att prövas får de en fullständig innebörd och verklighetsanknytning.

(Dewey, 1997, s. 206) 
Kunskapsutveckling innebär att aktivt söka klarhet utifrån upptäckten av något man inte förstår. Den värld vi lever i är inte statisk utan föränderlig, därför måste den enskilde individen lära sig handskas med framtida situationer och kunna lösa hitintills okända problem. Att då som är vanligt i skolan presentera lärostoffet som ett avslutat helt befrämjar inte elevernas tänkande, för att tänka innebär att fundera över händelsers betydelse för det som ska ske men som ännu inte har skett (Dewey, 1959b/1997).

Enligt Dewey är därför undervisningens tredje fas i hög grad en osäker fas. Att dra slutsatser innebär att ta ett språng från det kända till det okända. Där måste uppfinningsrikedom och påhittighet till. Den information som man redan har ger visserligen antydningar om hur sambandet mellan ett visst slags problem och dess lösning ser ut, men för att eleverna ska kunna lösa just det specifika problem som de ställts inför måste de gå utöver sina tidigare erfarenheter. Detta språng in i det nya är det sant kreativa elementet i tänkandet (ibid.). Eleverna prövar alltså sina idéer genom att omsätta dem i praktiken, vilket ger dem tillfälle att upptäcka värdet av sina nyvunna erfarenheter. Här kan man jämföra med uppfinnaren som genom att använda kända kunskaper på ett nytt sätt eller i ett nytt sammanhang skapar nya artefakter. Denna fas, som alltså följer på analysfasen, kallas här för "konstruktion/visualisering".

Så här långt har teknikre-presentation beskrivits som en process som tar sin början i formulerandet av ett uppdrag, för att sedan gå vidare med en analys vilken med hjälp av det så kallade reflektiva tänkandet förmår urskilja den relation mellan handlingar och deras resultat som ingår i alla typer av teknisk produktion och bearbetning. Analysfasen sades i sin tur följas av en kreativ fas, konstruktionen/visualiseringen, i vilken erfarenheter gjorda i det förflutna används för att kunna åskådliggöra nya lösningar på erkända problem eller uppdrag. Men som har noterats flera gånger vid det här laget är det viktigt att eleverna under hela teknikre-presentationsprocessen ges tillfälle att förankra sin egen gestaltande eller visualiserande aktivitet inom ett socialt och kulturellt sammanhang. Eleverna måste alltså få tid och möjlighet till att stanna upp, fundera och ställa frågor. Reflektion kan också göras skriftligen eller genom olika samtalsformer. Fasen utvärdering/reflektion behöver alltså nödvändigtvis inte avsluta teknikre-presentationen utan kan tillåtas avbryta den vid vilket steg som helst, t.ex. i samband med analysen. Även i detta sammanhang är Deweys idé om det reflektiva tänkandet är till hjälp, eftersom ett sätt att undersöka konsekvenserna av t.ex. olika typer av tekniska system är att se på deras sociala betydelse.

Som jag ser det ger Heidegger och Dewey ett tydligt stöd åt idén att teknikundervisningen bör inriktas mot förståelse och reflektion. Det handlar inte om att utbilda elever till tekniker, dvs. endast förse dem med vissa hantverksmässiga färdigheter, utan om att eleverna ska kunna förstå tekniken i bemärkelsen få insikt i den tekniska kulturens tradition och utveckling, bedöma och värdera konsekvenserna av hur teknik påverkar människan, samhället och miljön. Utifrån Heidegger blir skillnaden mellan dessa två perspektiv särskilt tydlig: det är en sak att utbilda elever i tekniskt kunnande och hantverk, en annan att ge dem förmågan att reflektera över teknikens roll i vårt nutida samhälle i syftet att kunna leva ett rikt, aktivt och ansvarstagande liv.

Som redan nämnts tar Heidegger avstånd från bildningsbegreppet, eftersom han förknippar det med idén om en förebild i enlighet med vilken människan utbildar sig och på så sätt rättar sig efter något som redan är bestämt. Jag förstår Heidegger så att han vill framhäva att den eftertanke och kritiska reflektion som han efterlyser varierar med erfarenhet, kontext och tid. Det gäller att förstå det faktiska och konkreta i den vanliga värld vi lever i. Även om Heidegger framhäver att besinning inte är ett bildande, så kan man ta hjälp av hans idé om besinning för att utveckla ett begrepp om bildning som tar fasta på den betydelse av skapande och formande som ligger i verbet "bilda", från vilket ordet "bildning" härstammar. Det är bland annat detta som jag har velat fånga med begreppet "teknikre-presentation": Ett sådant bildningsbegrepp är nära knutet till processen där eleverna just skapar eller formar sin världsbild genom en ständigt pågående omgestaltning av erfarenheter. 
På detta sätt kan man alltså kombinera det klassiska perspektivet på tekniken, vilket ger en insikt i teknikens struktur, olika system, artefakter, etc., med en reflektion över teknikens förutsättningar och samhälleliga betydelse. Resultatet är, som redan nämnts, förståelse av teknik som teknikre-presentation, med sina fyra faser: uppdragsformulering, analys, konstruktion/visualisering, utvärdering/reflektion. Metodens generella faser är tänkta att underlätta och rikta undervisningen för läraren, sedan är det lärarens eget sätt att hantera situationer som tillsammans med eleverna formar undervisningsprocessen. Denna varierar alltså med lärare, elever och det samhälle som undervisningen sker i. För elevens del handlar det om att uppöva en blick för situationens möjligheter och ett ansvarstagande för den egna aktiviteten. Här kan man klart se en förskjutning från en lärosituation där läraren förmedlade ett färdigt stoff, till ett aktivt deltagande från lärarens sida. Dewey (1959b/1997) skriver att i en sådan gemensam aktivitet är läraren elev och eleven lärare på en och samma gång.

\section{TEKNIKRE-PRESENTATION - EN SAMMANFATTNING}

Man skulle kunna sammanfatta de olika faserna i teknikre-presentation på följande sätt: I den första fasen, där fokus ligger på uppdragsformulering, utgår man från platsen, dvs. elevens verklighet, där elevens erfarenhet och intresse utgör utgångspunkten för val av artefakt eller tekniskt system, t ex ett tekniskt system kopplat till boende.

Varje uppdrag förutsätter en ingående analys av produktens eller systemets utveckling, funktion och uppbyggnad, samt en utvärdering av dess för- och nackdelar när det gäller dess effekter på natur, samhälle och individens livsvillkor. Analysen handlar ofta om ett omfattande efterforskningsarbete som kanske utgör den tyngsta och mest tidskrävande delen av ett uppdrag. Här gäller det för eleverna att skaffa sig kunskap om befintliga tekniska system, t.ex. om husets historia, olika system i huset, dess konstruktion, etc. Dessutom kan eleverna också söka kunskap direkt knuten till designprocessen, t.ex. en skiss, ritning eller modell.

Den tredje fasen är visualisering eller konstruktion av förståelse. Kommunikation med hjälp av skisser, beskrivningar, modeller och simuleringar, som visar elevens förståelse. Denna fas innebär att man som lärare organiserar aktiviteter som successivt utvecklar elevernas förståelse och för eleverna att de arbetar med att bygga upp sin förståelse och visar att de har tillägnat sig den.

Både under och efter avslutat arbete ges eleverna tillfälle till reflektion och utvärdering. För att undervisningsprocessen ska leda framåt är det viktigt att elevernas tankar i samband med gestaltningen synliggörs på olika sätt. Teknikre-presentation kännetecknas av att den som skapat modellen gör det i relation till verkliga förebilder. Sådana förebilder kan vara tekniken i hemmet eller i närområdet, bilder, filmer, böcker och mycket annat. Det kan också vara kamraternas skisser och modeller i skolan. Genom att iaktta andras modeller kan eleverna upptäcka nya samband mellan olika gestaltningsidéer och erhålla större förståelse av hur den egna konstruktionen kan utvecklas. Men reflektionen i form av analys handlar inte bara om att utveckla den egna modelleringstekniken, utan i lika hög grad om att förstå samhällets teknik.

Förståelse är något som utvecklas över tid, genom att man får tillfälle till en mångfald av förståelsehandlingar. Genom att arbeta kontinuerligt med teknikre-presentation kan elevernas förståelse för den teknik som omger oss utvecklas.

När platsen sätts in i hela teknikre-presentationens sammanhang kan en modell se ut som i figur 1. 


\section{PLATSEN}

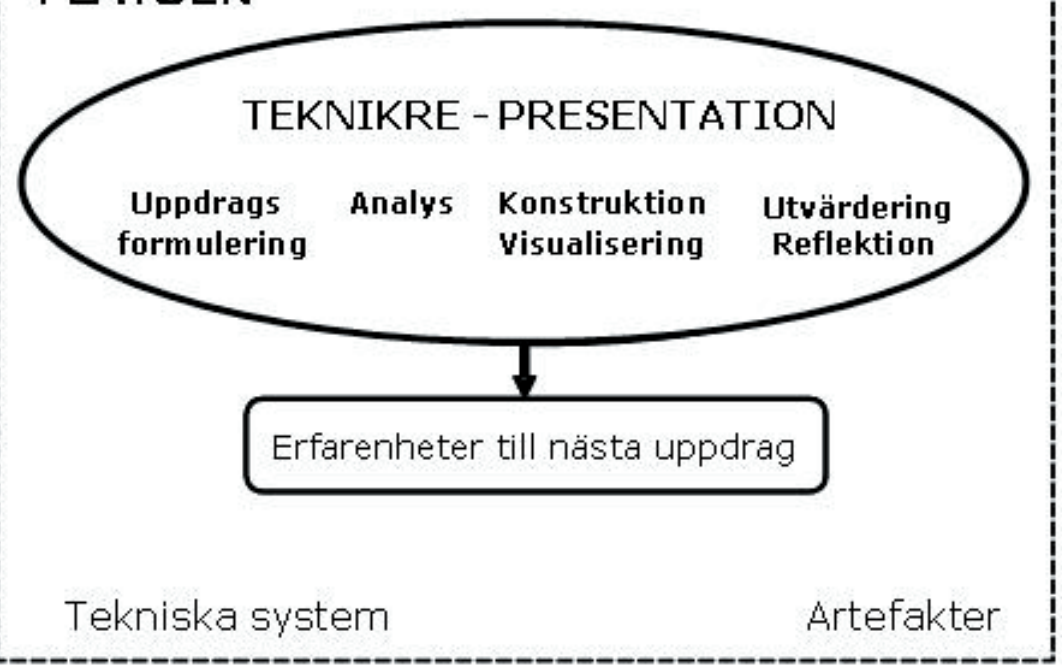

Figur 1

\section{ETT PRAKTISKT EXEMPEL PÅ TEKNIKRE-PRESENTATION}

Ett exempel från årskurs 6, visar på hur en planerad förändring i närmiljön användes som uppgift i teknikundervisningen. Kommunen planerade att bygga ett höghus i skolans närhet som skulle förändra landskapsbilden. Tidningarna var fyllda av artiklar och insändare som berörde ämnet. De olika faserna i elevernas teknikre-presentationsprocess illustreras kortfattat i Appendix.

\section{REFERENSER}

Aristoteles (1988). Den nikomachiska etiken, övers. M. Ringbom. Göteborg: Daidalos

Blomdahl, E. (2005). Towards a philosophy of technology education based on Heidegger and Dewey. I L. Lindström (red.) Technology education in new perspectives (s. 103-126). Stockholm: HLS Förlag.

Bruner, J. (1970). Undervisningsprocessen. Lund: Gleerups

Bruner, J (1990). Acts of meaning. Cambridge: MA: Harvard University Press

Dewey, J. (1959a). Dewey on education: selections. New York: Teachers College, Columbia University

Dewey, J. (1959b). Democracy and Education: An Introduction to the Philosophy of Education New York: Macmillan

Dewey, J. (1997). Demokrati och utbildning, övers. N. Sjödén. Göteborg: Daidalos

Fabricius, T., Malm, I. \& Pisilä, S. (2002). Skolinspektörernas halvårsrapport 2001: grundskolan. Stockholm: Utbildningsförvaltningen

Ginner, T. (in press). Uppföljning av enkätundersökningen Hur står det till med tekniken? CETIS enkätundersökning (2003/2004). Linköping: Centrum för tekniken i skolan.

Hagberg, J-E. \& Hultén, M. (2005). Skolans undervisning och elevers lärande i teknik - svensk forskning $i$ internationell kontext. Vetenskapsrådets rapportserie 2005:6

Heidegger, M. (1974). Teknikens väsen och andra uppsatser, övers. R. Matz. Uddevalla: Raben \& Sjögren

Heidegger, M. (2004). Vorträge und Aufsätze, 10:e utg. Stuttgart: Klett-Cotta 
Kress, G. (2003). Literacy in the New Media Age. London \& New York: Routledge

Mitcham, C. (1994). Thinking through technology: The path between engineering and philosophy. Chicago: University of Chicago Press.

Ortega y Gasset, J. (1957). Man and People. Översättning W.R. Trask. New York: W.W. Norton \& Company Inc.

Skogh, I-B. (2001). Teknikens värld - flickors värld. En studie av yngre flickors möte med teknik $i$ hem och skola. Stockholm: HLS Förlag

Skolverket (1994a). Lpo 94, Läroplan för grundskolan, 1994. Allmän del. www.skolverket.se

Skolverket (1994b). Lpo 94, Kursplaner för grundskolan, 1994/2000. www.skolverket.se

Summerton, J. (1998). "Stora tekniska system - en introduktion till forskningsfältet". I P. Blomkvist \& A. Keijser (red.), Den konstruerade världen (s. 19-43). Stockholm/Stehag: Brutus Östlings Bokförlag Symposion

Säljö, R. (2000). Lärande i praktiken. Stockholm: Prisma

Williams, J. (1996). "Philosophy of technology education", I J. Williams \& A. Williams (red.), Technology Education for Teachers. (s. 27-62). Australia: Macmillan 